\title{
Do we underestimate the impact of roads on arboreal animals? Roadkill as an important threat to Chaetomys subspinosus (Mammalia: Rodentia)
}

\author{
Ana Carolina Srbek-Araujo ${ }^{1,2 *} \mathbb{D}^{\text {, Aline de Castro Alvarenga }}{ }^{1}$ \& Ariane Teixeira Bertoldi ${ }^{1}$ \\ ${ }^{1}$ Universidade Vila Velha, Programa de Pós-Graduação Stricto Sensu em Ecologia de Ecossistemas, Rua \\ Comissário José Dantas de Melo, 21, Boa Vista, 29102-920, Vila Velha, ES, Brasil \\ ${ }^{2}$ Instituto SerraDiCal de Pesquisa e Conservação, Belo Horizonte, MG, Brasil \\ *Corresponding author: Ana Carolina Srbek-Araujo, e-mail: srbekaraujo@hotmail.com
}

SRBEK-ARAUJO, A. C.; ALVARENGA, A. C.; BERTOLDI, A. T. Do we underestimate the impact of roads on arboreal animals? Roadkill as an important threat to Chaetomys subspinosus (Mammalia: Rodentia). Biota Neotropica. 18(3): e20170511. http://dx.doi.org/10.1590/1676-0611-BN-2017-0511

\begin{abstract}
The Thin-spined Porcupine (Chaetomys subspinosus) is a medium-sized and mainly arboreal rodent, endemic to the Brazilian Atlantic Forest, and threatened with extinction. Habitat loss, hunting, forest fires, agriculture and livestock are threats identified for the species. Here we raise the alert to the impact of roads on remaining populations of $C$. subspinosus based on roadkill records from the state of Espírito Santo, southeastern Brazil. Mortality due to roadkill is likely to impact C. subspinosus in different regions of the state, and is a widespread problem, not unique to a single location or population. The pattern of roadkills in the studied regions suggest that the species is more susceptible to collisions with vehicles in the breeding period. Additionally, concrete barriers that divide lanes on highways seens to increase the likelihood of roadkill for Thin-spined Porcupines. We recommend that roadkill should be included in the list of threats to C. subspinosus in the Espírito Santo. Mortality due to roadkill is probably relevant also for populations in the states of Bahia and Sergipe, and it should be evaluated locally. The installation of road-crossing structures for wildlife, such as arboreal overpasses, is recommended on roads crossing or close to protected areas with C. subspinosus presence in Espírito Santo and elsewhere.
\end{abstract}

Keywords: Atlantic Forest, protected areas, road ecology, Thin-spined Porcupine.

\section{Estaríamos subestimando o impacto de estradas sobre espécies arborícolas? Atropelamento de fauna como uma importante ameaça para Chaetomys subspinosus (Mammalia: Rodentia)}

\begin{abstract}
Resumo: O ouriço-preto (Chaetomys subspinosus) é um roedor essencialmente arborícola, de médio porte, endêmico da Mata Atlântica brasileira. Atualmente está classificado como Vulnerável à extinção. Perda de habitat, caça, incêndios florestais, agricultura e pecuária são identificados como ameaças para a espécie. A presente comunicação alerta para o impacto de estradas sobre as populações remanescentes de C. subspinosus com base em registros de atropelamento obtidos no estado do Espírito Santo, sudeste do Brasil. Os registros aqui apresentados indicam que a morte de espécimes devido a atropelamentos afeta populações de C. subspinosus em diferentes regiões do estado, sendo um problema generalizado, não consistindo em ameaça para uma única localidade ou população. O padrão observado nas regiões estudadas sugere que a espécie é mais suscetível a atropelamentos durante o período reprodutivo. Além disso, a presença de barreiras de concreto dividindo as faixas das rodovias parece aumentar a ocorrência de atropelamentos de ouriços-pretos. Recomenda-se que o atropelamento de espécimes seja incluído entre as ameaças à conservação de C. subspinosus no Espírito Santo, podendo representar uma ameaça relevante para a espécie também nos estados da Bahia e Sergipe, o que deve ser avaliado localmente. A instalação de estruturas para transposição rodoviária pela fauna, como passagens aéreas, é recomendada para estradas que atravessam ou que estão associadas a áreas protegidas com confirmação da presença de C. subspinosus no Espírito Santo e em outros estados.
\end{abstract}

Palavras-chave: áreas protegidas, ecologia de estradas, Mata Atlântica, ouriço-preto. 


\section{Introduction}

The Thin-spined Porcupine (Chaetomys subspinosus Olfers, 1818) is a medium-sized, almost entirely arboreal, nocturnal and folivorous rodent in the Family Erethizontidae (Chiarello et al. 1997, Giné et al. 2010, Souto Lima et al. 2010). It is endemic to the Atlantic Forest where its historical range extends from northern Rio de Janeiro to southern Sergipe (Oliver \& Santos 1991). Recent porcupine sighting records are restricted to a narrow strip along the coast from southern Espírito Santo to Sergipe (Oliveira et al. 2011). Remaining populations of C. subspinosus are declining (Faria et.al. 2011, Catzeflis et al. 2017) and the species is classified as Vulnerable (Brasil 2014, Catzeflis et al. 2017). The National Action Plan for the Conservation of the Thin-spined Porcupine lists its main threats as habitat loss and fragmentation due to real estate and other infrastructure development which destroy natural habitat, poaching that is common in rural areas near almost all remaining populations, forest fires that cause mortality due to mainly arboreal habits and because they sheltering in tangles of vines (limit their ability to escape from fires), and agriculture (including livestock grazing) with agrochemical use and pasture clearing at the edges of the remaining forest fragments (Faria et al. 2011).

Habitat loss and habitat fragmentation modify all aspects of the landscape (Forman \& Alexander 1998, Forman \& Deblinger 2000, Trombulak \& Frissell 2000), and are usually associated with roads. Roads inhibit animal movement and may often be barriers (total or partial) for many animal species and thus cause isolation of populations, especially important for threatened species (Forman \& Alexander 1998, Trombulak \& Frissell 2000). Arboreal mammals depend on trees, rarely travel on the ground, and are vulnerable to habitat fragmentation (Lancaster et al. 2011). For these reasons, the impact of roads may be even more important for arboreal than terrestrial species, especially when causing genetic isolation of populations (Taylor et al. 2011). In addition to potential isolation of populations by roads themselves, roadkill as a consequence of crossing roads is an extremely important anthropogenic cause of mortality for vertebrates worldwide (Forman \& Alexander 1998) and few species are immune to this threat (Trombulak \& Frissell 2000).

Locomotion, ecology and behavior all determine wildlife vulnerability to roadkill, and slow-moving, predominantly arboreal habits (with occasional forays across open ground) and the tendency to freeze in response to approaching vehicles, along with relatively poor eyesight, are some of the characteristics that make species especially susceptible to roadkill (Laurance et al. 2009). Erethizontids hear well and have good olfaction but poor vision (Vaughan et al. 2000). Chaetomys subspisosus is slow-moving within the canopy, never jumping, but rather carefully traversing tree to tree (Faria et al. 2011, Oliveira et al. 2012). This porcupine rarely descends to the forest floor, using the ground to cross between trees separated by a few meters when canopies do not permit arboreal travel (Oliveira et al. 2012). Thus, $C$. subspisosus is often vulnerable to roadkill.

Here, using roadkill records from different places in Espírito Santo, we raise the alert to the impact of roads on the remaining populations of C. subspinosus in the Atlantic Forest of Brazil.

\section{Material and Methods}

We gathered primary (our unpublished data) and secondary (records published by other authors) data of roadkills in three regions in the state of Espírito Santo: Coastal Corridor Jucu-Setiba-Benevente (Corredor Costeiro Jucu-Setiba-Benevente - CCJSB; $20^{\circ} 23^{\prime}-20^{\circ} 47^{\prime} \mathrm{S}$ and $40^{\circ} 19^{\prime}$ $40^{\circ} 40^{\prime}$ W), municipalities of Vila Velha, Guarapari and Anchieta, in the central-southern coast; Pedra Azul State Park region (Parque

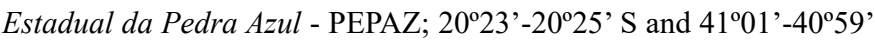
W; 1,240 ha), municipality of Domingos Martins, in the south-central mountains; and Linhares-Sooretama Block (Bloco Linhares-Sooretama BLS; $18^{\circ} 53^{\prime}-19^{\circ} 15^{\prime}$ S e $39^{\circ} 44^{\prime}-40^{\circ} 16^{\prime} \mathrm{W}$; 50,000 ha), between the municipalities of Linhares and Jaguaré, in the north (Figure 1).

The CCJSB comprises the Jacarenema Municipal Natural Park (Parque Natural Municipal de Jacarenema - PNMJ; 346 ha), the Setiba Environmental Protection Area (Área de Proteção Ambiental de Setiba - APA Setiba; 12,960 ha) and Paulo César Vinha State Park (Parque Estadual Paulo César Vinha - PEPCV; 1,500 ha), among other remnants of native vegetation (including priority areas for conservation in Espírito Santo). The PNMJ includes forest, flooded forest associated with the Jucu river, mangrove, and vegetation of restinga (relatively sparse to dense shrubs and forests found on sandy coastal plains) near the beach. The APA Setiba includes land and sea surrounding the PEPCV. The land area of APA Setiba and PEPCV are on sandy coastal plains and comprise different communities of restinga vegetation (forest, flooded and non-flooded shrub vegetation and floodplain). Records of Thin-spined Porcupine roadkills in the CCJSB region were on highway ES-060 (regionally called Rodovia do Sol) where it comes in contact with protected areas ( $\sim 3 \mathrm{~km}$ in PNMJ and $\sim 15 \mathrm{~km}$ in APA Setiba and PEPCV) and other remnants (Figure 1). Wildlife roadkills have been systematically monitored here daily since 2001 and is carried out by an observer traveling by car along a $67.5 \mathrm{~km}$ section of road that includes some urban areas. Roadkill data (from 2001 to 2015) are available at the Concessionária Rodovia do Sol (2016). The date and approximate geographic location of each roadkilled C. subspinosus were provided by the team of the Program for the Protection and Monitoring of Wild Animals $E_{\text {E }}$ Bicho developed by the Concessionária Rodovia do Sol S.A. This monitoring is among the legal conditions for operation of highway ES-060 (Condition $n^{\circ} 27$ of Operating License 03/03 - IEMA).

The PEPAZ region comprises forests, including high altitude forest, and vegetation associated with rock formations. Records of C. subspinosus on the PEPAZ region are from our monthly surveys (primary data) carried out from January to December 2015, on the stretch of the highway BR-262 that borders the park. A $20 \mathrm{~km}$ section (from $\mathrm{km} 74$ to 94 ) was traveled by car with two researchers (one driver and one observer) at an average speed of $50 \mathrm{~km} / \mathrm{h}$ during five consecutive days each month.

The BLS comprises the Sooretama Biological Reserve (Reserva Biológica de Sooretama - RBS; 24,250 ha), the Vale Natural Reserve (Reserva Natural Vale-RNV; 22,711 ha) and two other nearby protected areas (Private Reserve of Natural Heritage, Reserva Particular do Patrimônio Natural - RPPN Recanto das Antas, of 2,212 ha, and RPPN Mutum Preto, of 379 ha). The BLS includes a mosaic of habitats in which dense lowland forest (Tabuleiro forest) is dominant. The BLS 

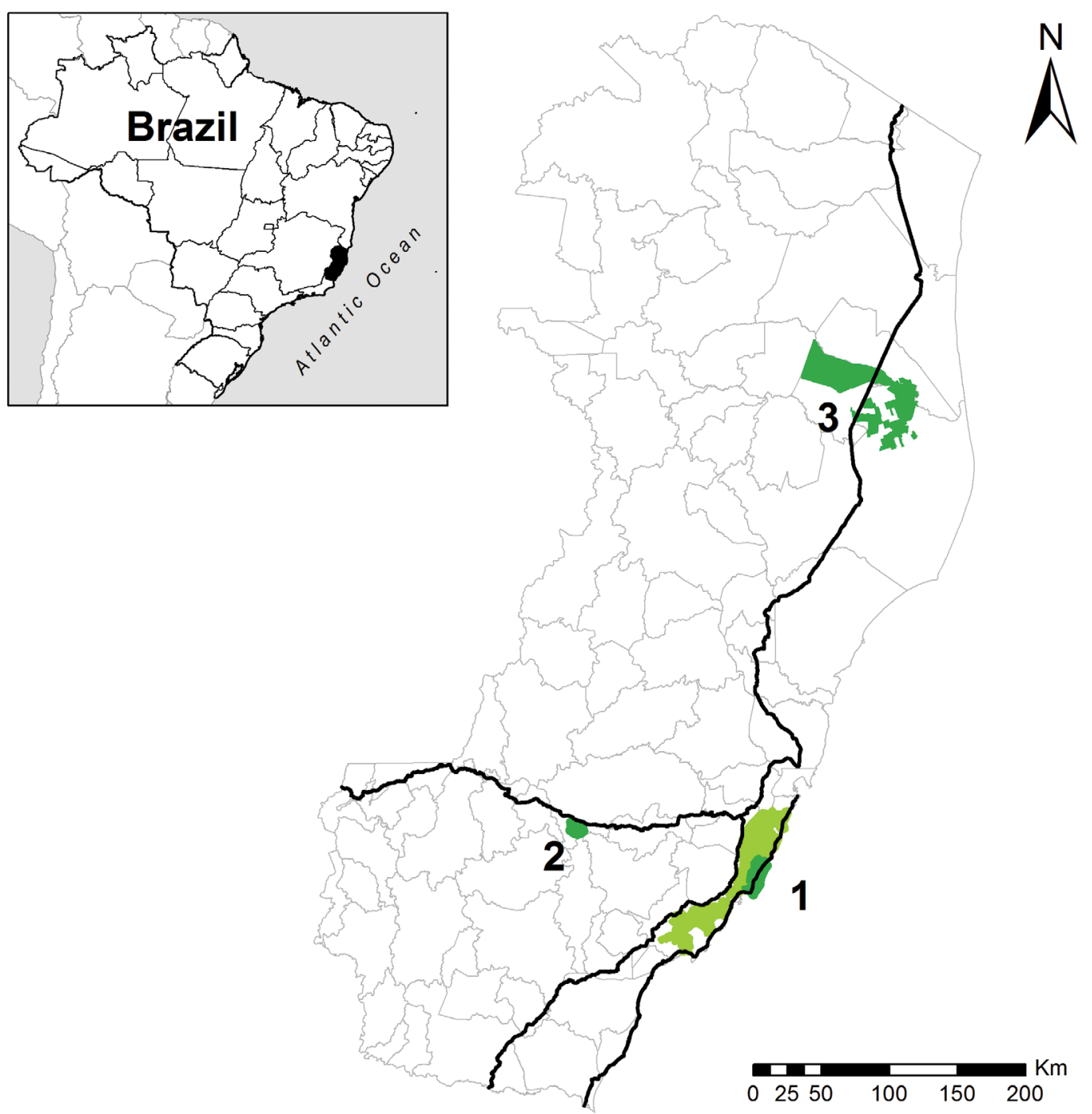

Figure 1. Location of the roadkills of the Thin-spined Porcupine (Chaetomys subspinosus) in Brazil (insert) and in the state of Espírito Santo: Coastal Corridor Jucu-Setiba-Benevente (light green), showing the Paulo César Vinha State Park and the land area of Setiba Environmental Protection Area (dark green; 1), Pedra Azul State Park (2) and Linhares-Sooretama Block (3). The roads associated with these regions and protected areas, where the records were obtained, are also indicated (south coast: ES-060; east-west: BR-262; north-south: BR-101).

is intersected by highway BR-101where the Thin-spined Porcupine roadkill was found ( $\sim 15 \mathrm{~km}$ of road). Wildlife roadkills on BR-101 where it contacts the BLS are systematically monitored daily by car or on foot (A. Banhos, personal communication). A set of roadkill records from 2011 to 2014 is available in Klippel et al. (2015) and was used by us as source for roadkill in the northern part of the state. That study did not report all roadkilled mammals during the period, and so the data should be used only for qualitative purposes.
BR-262 and the BR-101 are one-lane roads with a shoulder on both sides in the region where they are monitored. ES-060 is a single lane road to $\mathrm{km} 12$ where it becomes two lanes separated by a divide to $\mathrm{km}$ 40 , followed by a concrete curb barrier between $\mathrm{km} 40$ and 50, where it once again becomes single lane (Concessionária Rodovia do Sol 2016). PNMJ is between $\mathrm{km} 11$ and 14, PEPCV between $\mathrm{km} 29$ and 40, and APA Setiba between km 27 and 43 of ES-060. The tree canopy does not reach over the roads in any of the studied areas, and so arboreal animals must cross the road when they move from one side to the other. 
Roadkills of other arboreal mammal species were available in the records we analyses and also were recorded in PEPAZ region. We include the list of species in this study to demonstrate that many additional arboreal species are affected by roads in the studied regions, and also deserve special attention in conservation and management plans as well.

\section{Results and Discussion}

Fifteen C. subspinosus were killed by collisions with vehicles between 2002 and 2015 on the ES-060 along the CCJSB, and roadkill rate increased since 2009 (Concessionária Rodovia do Sol 2016; Table 1). Oliveira et al. (2015) also reported a specimen found dead after being hit by a vehicle on highway ES-060, in February 2012, near PEPCV, but this animal was included in previous counts (Table 1). Roadkilled Thin-spined Porcupines in the CCJSB were only found from October to February (Table 1), and were in 13 locations in a 50 $\mathrm{km}$ length of road, with a distance between roadkills of 1 to $13 \mathrm{~km}$. Six roadkills ( $\sim 40 \%$ ) occurred along the section of highway that was two-lane and separated by the concrete barrier. We found two roadkilled porcupines while sampling along the PEPAZ region: January 2015 $\left(20^{\circ} 23^{\prime} 27^{\prime \prime} \mathrm{S}\right.$ and $\left.41^{\circ} 00^{\prime} 36^{\prime \prime} \mathrm{W}\right)$ and December $2015\left(20^{\circ} 22^{\prime} 47^{\prime \prime} \mathrm{S}\right.$ e $41^{\circ} 02^{\prime} 19$ " W, Table 1$)$. The dead animals were $3 \mathrm{~km}$ apart and where both sides of the road were forested. One porcupine roadkill was reported for BLS (Klippel et al. 2015), and the animal was found in October 2013 (Table 1).
The pattern of roadkills in these three regions suggest that $C$. subspinosus is more susceptible to collisions with vehicles from October to February. As such, this risk is likely to be associated with the breeding period, when animals travel in search of mates, including between forest fragments that require crossing roads. Records of infant Thin-spined Porcupines were reported from December to February in southern Bahia (Giné 2009) and in March at the PEPCV (Oliveira et al. 2012). If C. subspinosus is more vulnerable to roadkills in the reproductive period, mortality during breeding is likely to cause even greater population decline (loss of individuals and reduction in fecundity). If so, specific seasonal actions to protect the species during breeding when on-ground travel is most likely causing exposure to auto traffic are absolutely necessary.

The data from the CCJSB also suggest that concrete barriers that divide lanes on highways can increase the likelihood of roadkill for Thin-spined Porcupines, and so this possibility (and alternatives to reduce roadkill) should be examined in future studies. Concrete barriers impede wildlife movement, reduce landscape permeability and can trap or confuse animals as they cross highways, thereby increasing the time they spend in the roadway and the risk of roadkill (Clevenger \& Kociolek 2013). We also find that roadkilled porcupines are dispersed over the landscape and not concentrated in any one location. Therefore, the elements of the landscape that favor this species attempt of highway crossing should be evaluated. Also, with the uncertainty of the exact number of animals that were hit by cars but not immediately killed and which wandered off to die in the forest (and therefore not reported), the

Table 1. Thin-spined Porcupine (Chaetomys subspinosus) roadkills reported in the state of Espírito Santo, Brazil. The road and the protected area or region it is associated with or near, the number of samples (NS), date and source are included.

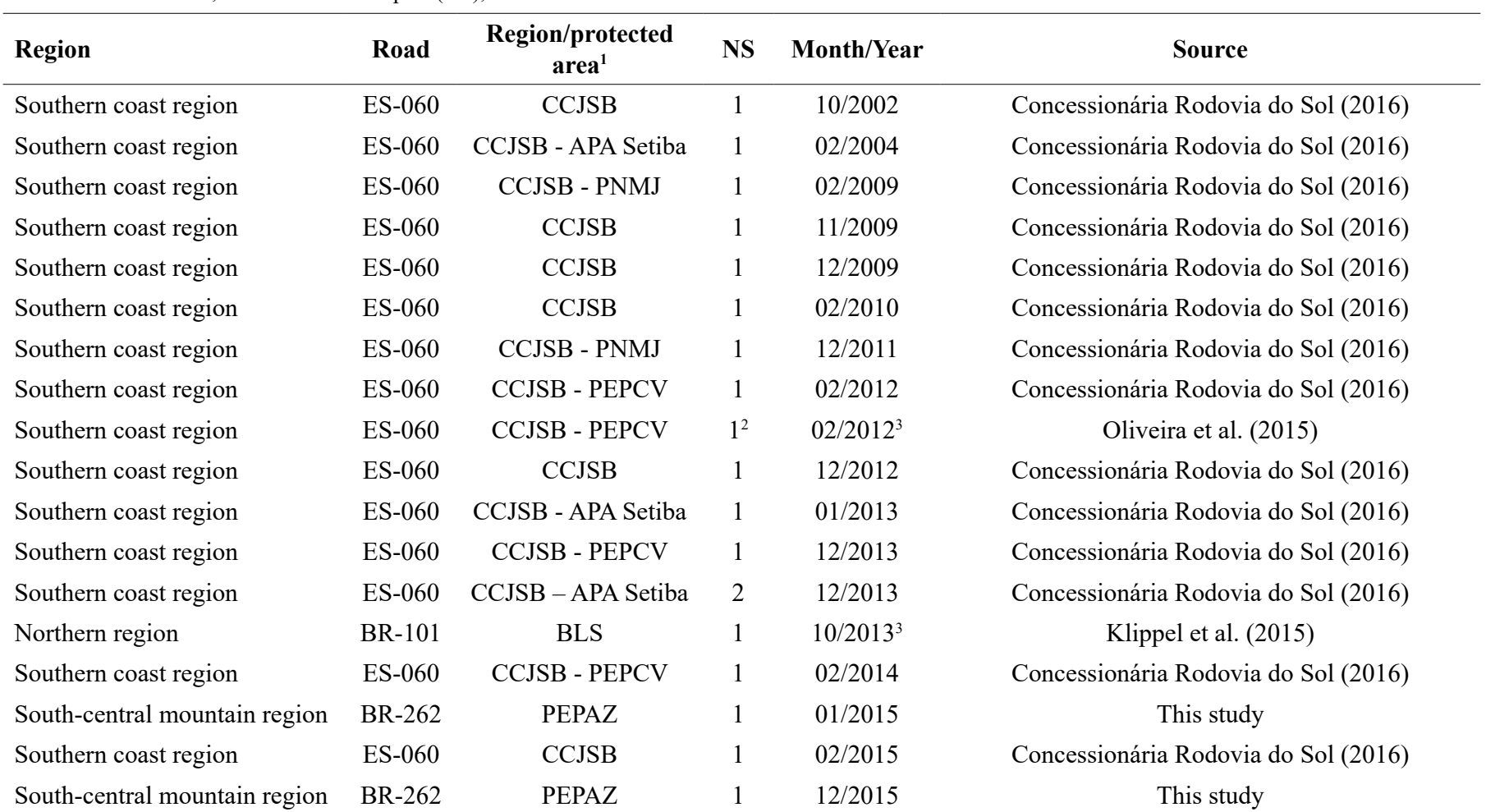

${ }^{1}$ Region/protected area: CCJSB $=$ Coastal Corridor Jucu-Setiba-Benevente; PNMJ = Jacarenema Municipal Natural Park; APA Setiba $=$ Setiba Environmental Protection Area; PEPCV = Paulo César Vinha State Park; PEPAZ = Pedra Azul State Park; BLS $=$ Linhares-Sooretama Block. ${ }^{2}$ This record corresponds to the specimen cited in the above-mentioned reference. ${ }^{3}$ The month of this roadkill record was informed personally by the authors of the paper cited. 
solutions to avoid roadkill should be considered in any region where roads pass through natural areas.

The Thin-spined Porcupine may have been continuously distributed throughout its original range, but Atlantic Forest has since been several subdivided by anthropic forest fragmentation, thereby causing genetic divergence between remaining isolated populations, and drastic reduction in the gene pool of the species (Oliveira et al. 2011). Thus, additional mortality associated with highways will cause further reduction of the remaining populations and reduce gene flow (and genetic variability) both on a local scale and throughout its current, fragmented, distribution. We highlight that the mortality of specimens may have more severe effects on genetic diversity (due to depletion) than does the barrier effect, and migration is usually insufficient to recoup the genetic variation lost as a result of road mortality (Jackson \& Fahrig 2011). Additional negative impacts of roads is a consequence of additional forest lost and fragmentation usually accompanying roads due to human occupation, along with the introduction of invasive species and the increase in hunting pressure (Trombulak \& Frissell 2000), all of which can affect porcupines (Faria et al. 2011, Oliveira et al. 2012).

The remaining area occupied by $C$. subspinosus is extremely fragmented, and only $17 \%$ of its current distribution includes intact forest and restinga vegetation (Catzeflis et al. 2017). In Espírito Santo, the porcupine has been found in only seven protected areas, including the PEPCV and BLS (Faria et al. 2011). Roadkill records in PEPAZ region are the first confirmed evidence of Thin-spined Porcupines in this protected area. Today, in addition to the presence of the species in a small number of areas, all protected areas with records of $C$. subspinosus are associated with or near roads.

Because C. subspinosus is almost exclusively arboreal, moving on the ground only when no options of arboreal travel are available, we might have expected a greater rate of roadkill everywhere. The few records, or absence of records in many regions is likely to be due to the lack of studies or the nature of sporadic examinations of roadkills, plus the unknown number of animals hit by cars that were not immediately killed. Regardless, the remaining populations are likely to be small (due to low abundance and habitat fragmentation, Faria et al. 2011) which further reduces the rate of roadkills when animals risk crossing roads. Furthermore, the low roadkill rate in some regions may also be due to the existence of a barrier effect caused by roads on C. subspinosus (less evident in the reproductive period, as suggested here). This emphasizes the isolation of remaining populations, highlighting that some regions are composed by small habitat fragments.

In addition to C. subspinosus, another seven arboreal mammal species were also recorded killed on the roads within the studied regions (Table 2). Arboreal animals in the genera Callithrix and Coendou were the most common roadkills. For Callithrix, this is likely to be due to their living in social groups (often up to 7 individuals) which habitually cross open ground (Eisenberg \& Redford 1999). Coendou porcupines are similar in locomotion and biology to the Thin-spined Porcupine (see Introduction for details), which may explain why they are commonly found dead on roads. Additionally, they are more abundant and often common in some places (Roach \& Naylor 2016a, 2016b), with ground feeding behavior for which they descend to the ground more often (Abreu et al. 2016). Among the roadkilled arboreal species, Callithrix flaviceps is also threatened with extinction (Endangered; Rylands et al. 2008, Brasil 2014). These data indicate that other arboreal species also can be threatened by being hit by vehicles on highways, and the impact of roads on these groups also may be underestimated, as we propose for C. subspinosus. We highlight that while many roadkills are likely to be associated with population density, roadkills are not good estimates of population size and should be accompanied by other measures of abundance to more accurately access risk. Additionally, the greatest number of records found in the CCJSB region should be due to the fact that this region was sampled more often, illustrating the importance of daily sampling to better estimate the impact of roadkill on wildlife.

We find that the Thin-spined Porcupine is likely to be threatened by the possibility of roadkill in different regions in the state of Espírito Santo, which is a widespread problem, not unique to a single location or population. We recommend that roadkill should be treated as an important threat to the species in this state and elsewhere. Mortality due to roadkill is probably relevant also for populations in the states of Bahia and Sergipe, and it should be evaluated locally. Future studies

Table 2. Other arboreal mammals recorded as roadkills in the state of Espírito Santo, Brazil, in addition to the Thin-spined Porcupine (Chaetomys subspinosus). See Material and Methods.

\begin{tabular}{llcc}
\hline Species & Common name & CCJSB $^{\mathbf{1}}$ & PEPAZ $^{\mathbf{2}}$ \\
\hline $\begin{array}{l}\text { Order Pilosa } \\
\quad \text { Bradypus variegatus Schinz, 1825 }\end{array}$ & 0 & 0 \\
$\begin{array}{l}\text { Order Primates } \\
\quad \text { Alouatta guariba clamitans Cabrera, 1940 }\end{array}$ & Brown-throated Sloth & 1 & 1 \\
$\quad$ Gregorin 2006, Rylands \& Brandon-Jones 1998) & Brown Howler Monkey & 2 & 0 \\
$\quad$ Callithrix flaviceps (Thomas, 1903) & Buffy-headed Marmoset & 0 & 1 \\
$\quad$ Callithrix geoffroyi (Humboldt, 1812) & Geoffroy's Tufted-ear Marmoset & 192 & 1 \\
$\quad$ Sapajus nigritus (Goldfuss, 1809) & Black-horned Tufted Capuchin & 2 & 0 \\
Order Rodentia & & 3 & 0 \\
$\quad$ Chaetomys subespinosus (Olfers, 1818) & Thin-spined Porcupine & 15 & 0 \\
$\quad$ Coendou spinosus (F. Cuvier, 1823) & Paraguayan Hairy Dwarf Porcupine & 0 & 2 \\
$\quad$ Coendou insidiosus (Lichtenstein, 1818) & Bahian Hairy Dwarf Porcupine & 124 & 22 \\
Total & & 334 & 0 \\
\hline
\end{tabular}

Source of records: ${ }^{1}$ Concessionária Rodovia do Sol (2016); ${ }^{2}$ This study; ${ }^{3}$ Klippel et al. (2015). 
should examine genetic isolation of populations on both sides of the roads to test for a barrier effect on C. subspinosus, as well as that of the effect of road mortality on the structure of the remaining populations. Additionally we recommend study of the biological (including behavior) and environmental factors that determine the vulnerability of $C$. subspinosus to roadkill, and the installation of road-crossing structures for wildlife, such as arboreal overpasses (such as design options proposed by Teixeira et al. 2013 and Ministry of Agriculture, Food and the Environment 2016). Arboreal overpasses should be made available immediately and especially on roads near or through protected areas where the Thin-spined Porcupine is found. Subsequent monitoring of overpasses should be carried out to confirm their use by the target species (Gregory et al. 2014). We emphasize that these arboreal overpasses are likely also to be used by other species and thereby will contribute to conservation of the arboreal community as a whole. Even if used by few individuals, those animals that use them will then contribute to the demographic and genetic connectivity of populations (Soanes et al. 2015, Soanes et al. 2018), reducing the loss of individuals by roadkill and contributing to the conservation of $C$. subspinosus (and other arboreal species) in different regions of Espírito Santo and elsewhere.

\section{Acknowledgments}

We would like to thank the Instituto Estadual de Meio Ambiente e Recursos Hídricos (IEMA) by the support in field activities in PEPAZ region; and the Concessionária Rodovia do Sol S.A., especially Franciane Almeida (SLau Ambiental), for granting access and permission to use the databases of the Program for the Protection and Monitoring of Wild Animals É o Bicho regarding the roadkill records of Chaetomys subspinosus on ES-060. We thank the anonymous reviewers for their valuable critiques and suggestions. ACA is grateful to the Coordenação de Aperfeiçoamento de Pessoal de Nível Superior (CAPES) for the postgraduate scholarship. ATB is grateful to the Fundação de Amparo à Pesquisa e Inovação do Espírito Santo (FAPES) for the postgraduate scholarship. ACS-A is grateful to the Universidade Vila Velha and Fundação de Amparo à Pesquisa e Inovação do Espírito Santo (FAPES 0607/2015 and 0510/2016), which sponsored the research of the Laboratório de Ecologia e Conservação de Biodiversidade (LECBio).

\section{Author Contributions}

Ana Carolina Srbek-Araujo: Concept and design of the study, data collection, data analysis and interpretation, manuscript preparation. Aline de Castro Alvarenga: Data collection, manuscript preparation. Ariane Teixeira Bertoldi: Manuscript preparation.

\section{Conflicts of interest}

The authors declare that they have no conflict of interest related to the publication of this manuscript.

\section{References}

ABREU, T.C.K., ROSA, C.A., AXIMOFF, I. \& PASSAMANI, M. 2016. New record of feeding behavior by the porcupine Coendou spinosus (F. Cuvier, 1823 ) in highaltitude grassland of the Brazilian Atlantic Forest. Mammalia 81(5):523-526,

BRASIL. 2014. Lista Nacional das Espécies da Fauna Brasileira Ameaçadas de Extinção. Ministério do Meio Ambiente, Brasília. http://www.icmbio.gov. br (last access on 29/06/2016).

CHIARELLO, A.G., PASSAMANI, M. \& ZORTÉA, M. 1997. Field observations on the thin-spined porcupine, Chaetomys subspinosus (Rodentia; Echimyidae). Mammalia 61(1):29-36.

CATZEFlis, F., PATTON, J., PERCEQUILlO, A., BONVICINO, C. \& WEKSLER, M. 2017. Chaetomys subspinosus. The IUCN Red List of Threatened Species 2017:e.T4366A22213335. http://dx.doi.org/10.2305/ IUCN.UK.2017-2.RLTS.T4366A22213335.en (last access on 28/12/2017).

CLEVENGER, A.P. \& KOCIOLEK, A.V. 2013. Potential Impacts of Highway Median Barriers on Wildlife: State of the Practice and Gap Analysis. Environ. Manage. (2013) 52: 1299-1312.

CONCESSIONÁRIA RODOVIA DO SOL. 2016. $28^{\circ}$ Relatório do monitoramento de animais silvestres atropelados na Rodovia do Sol (ES060). Concessionária Rodovia do Sol S.A., Vila Velha.

EISENBERG, J.F. \& REDFORD, K.H. 1999. Mammals of the neotropics the central neotropics. University of Chicago Press, Chicago,

FARIA, D., GINÉ, G.A.F. \& REIS, M.L. 2011. Plano de Ação Nacional para a Conservação do Ouriço-preto. Instituto Chico Mendes de Conservação da Biodiversidade, Brasília.

FORMAN, R.T.T. \& ALEXANDER, L.A. 1998. Roads and their major ecological effects. Annu. Rev. Ecol. Evol. Syst. 29:207-231.

FORMAN, R.T.T. \& DEBLINGER, R.D. 2000. The Ecological Road-Effect Zone of a Massachusetts (U.S.A.) Suburban Highway. Conserv. Biol. 14(1):36-46.

GINÉ, G.A.F. 2009. Ecologia e comportamento do ouriço-preto (Chaetomys subspinosus, Olfers 1818) em fragmentos de Mata Atlântica do município de Ilhéus, sul da Bahia. PhDthesis, Universidade de São Paulo, Piracicaba.

GINÉ, G.A.F., DUARTE, J.M.B. \& FARIA, D. 2010. Feeding ecology of a selective folivore, the thin-spined porcupine (Chaetomys subspinosus) in the Atlantic Forest. J. Mammal. 91(4):931-941.

GREGORY, T., CARRASCO RUEDA, F., DEICHMANN, J., KOLOWSKI, J. \& ALONSO, A. 2014. Arboreal camera trapping: Taking a proven method to new heights. Methods Ecol. Evol. 5:443-451.

JACKSON, N.D. \& FAHRIG, L. 2011. Relative effects of road mortality and decreased connectivity on population genetic diversity. Biol. Conserv. 144:3143-3148.

KLIPPEL, A.H., OLIVEIRA, P.V., BRITTO, K.B., FREIRE, B.F., MORENO, M.R., SANTOS, A.R., BANHOS, A. \& PANETO, G.G. 2015. Using DNA Barcodes to identify Road-Killed Animals in two Atlantic Forest Nature Reserves, Brazil. PLoS ONE 10(8): e0134877.

LANCASTER, M.L., TAYLOR, A.C., COOPER, S.J.B. \& CARTHEW, S.M. 2011. Limited ecological connectivity of an arboreal marsupial across a forestplantation landscape despite apparent resilience to fragmentation. Mol. Ecol. 20:2258-2271.

LAURANCE, W.F., GOOSEM, M. \& LAURANCE, S.G.W. 2009. Impacts of roads and linear clearings on tropical forests. Trends Ecol. Evol. 24(12):659-669

MINISTRY OF AGRICULTURE, FOOD AND THE ENVIRONMENT. 2016. Technical prescriptions for wildlife crossing and fence design. Documents for the mitigation of habitat fragmentation caused by transport infrastructure. Ministry of Agriculture, Food and the Environment, Madrid.

OLIVEIRA, C.G., MARTINEZ, R.A., GINÉ, G.A.F., FARIA, D.M. \& GAIOTTO, F.A. 2011. Genetic assessment of the Atlantic Forest bristle porcupine, Chaetomys subspinosus (Rodentia: Erethizontidae), an endemic species threatened with extinction. Genet. Mol. Res. 10(2):923-931. 
OLIVEIRA, P.A., LIMA, R.B.S. \& CHIARELLO, A.G. 2012. Home range, movements and diurnal roosts of the engangered thin-spined porcupine, Chaetomys subspinosus (Rodentia: Erethizontidae), in the Brazilian Atlantic Forest. Mamm. Biol. 77:97-107.

OLIVEIRA, R.S., RANGEL, M.C.V., ROSSI JR, J.L. \& BRAGA, F.R. 2015. Ocorrência de Endoparasitos em ouriços-cacheiros (Sphiggurus insidiosus) e ouriço-preto (Chaetomys subspinosus). Natureza on line 13(5):229-233.

OLIVER, W.L.R. \& SANTOS, I.B. 1991. Threatened endemic mammals of the Atlantic forest region of south-eastern Brazil. Wildlife Preservation Trust Special Scientific Report 4:1-126.

ROACH, N. \& NAYLOR, L. 2016a. Coendou insidiosus. The IUCN Red List of Threatened Species 2018: e.T20631A22213745. http://dx.doi.org/10.2305/ IUCN.UK.2016-2.RLTS.T20631A22213745.en (last access on 11/03/2018).

ROACH, N. \& NAYLOR, L. 2016b. Coendou spinosus. The IUCN Red List of Threatened Species 2018: e.T20630A22213974. http://dx.doi.org/10.2305/ IUCN.UK.2016-2.RLTS.T20630A22213974.en (last access on 11/03/2018).

RYLANDS, A.B., FERRARI, S.F. \& MENDES, S.L. 2008. Callithrix flaviceps. The IUCN Red List of Threatened Species 2018: e.T3571 A9951402. http:// dx.doi.org/10.2305/IUCN.UK.2008.RLTS.T3571A9951402.en (last access on $08 / 03 / 2018$ ).
SOANES, K., VESK, P.A. \& VAN DER REE, R. 2015. Monitoring the use of road-crossing structures by arboreal marsupials: insights gained from motion-triggered cameras and passive integrated transponder (PIT) tags. Wildlife Res. 42:241-256.

SOANES, K., TAYLOR, A.C., SUNNUCKS, P., VESK, P.A., CESARINI, S. \& VAN DER REE, R. 2018. Evaluating the success of wildlife crossing structures using genetic approaches and an experimental design: lessons from a gliding mammal. J. Appl. Ecol. 55:129-138.

SOUTO LIMA, R.B., OLIVEIRA, P.A. \& CHIARELLO, A.G. 2010. Diet of the thin-spined porcupine (Chaetomys subspinosus), an Atlantic forest endemic threatened with extinction in southeastern Brazil. Mamm. Biol. 75:538-546.

TAYLOR, A.C., WALKER, F.M., GOLDINGAY, R.L., BALL, T. \& VAN DER REE, R. 2011. Degree of Landscape Fragmentation Influences Genetic Isolation among Populations of a Gliding Mammal. PLoS ONE 6(10): e26651.

TEIXEIRA, F.Z., PRINTES, R.C., FAGUNDES, J.C.G., ALONSO, A.C. \& KINDEL, A. 2013. Canopy bridges as road overpasses for wildlife in urban fragmented landscapes. Biota Neotrop. 13(1):117-123.

TROMBULAK, S.C. \& FRISSELL, C.A. 2000. Review of ecological effects of roads on terrestrial and aquatic communities. Conserv. Biol. 14:18-30.

VAUGHAN, T.A., RYAN, J.M. \& CZAPLEWSKI, N.J. 2000. Mammalogy. Saunders College Publishing, Texas. 